\title{
Do Candidates Target Loyalists or Swing Voters? Beyond the Core- Versus Swing- Voter Debate
}

In the previous chapter, I have identified the typical characteristics of voters who were most likely to experience vote buying. Among a number of findings, the most consistent and intriguing was that a high level of party identification, that is, self-reported closeness to one of Indonesia's political parties, is a significant predictor. In this chapter, I turn in more detail to the interplay between party identification and vote buying. This linkage clearly relates to the core- versus swing-voter debate that has been the primary concern of much of the comparative literature on vote buying. At the centre of this debate is one key question: given the budgetary constraints candidates face, how and, especially, to whom do they distribute gifts to optimise their electoral prospects? As I will show in the following pages, most candidates and brokers repeatedly claim that they target partisan, loyalist voters. And as indicated in the previous chapter, voters with high levels of party identification are indeed - in relative terms - more likely to be targets of vote buying. But as the discussion below reveals, the number of party loyalists in Indonesia is small, leading to a situation in which the vast majority of vote buying-in absolute terms-happens among non-partisan voters. Hence, the main task of this chapter is to unpack this complex interrelationship between party identification, broker and candidate strategies, and the observed practice of vote buying on the ground.

(C) The Author(s) 2019

B. Muhtadi, Vote Buying in Indonesia, https://doi.org/10.1007/978-981-13-6779-3_4 
Given the centrality of party identification in attracting benefits, this chapter begins with descriptive data about the level of mass partisanship and its distribution across political parties in Indonesia. Then I consider whether the substantial effect of partisanship on vote buying reflects a case of reverse causality: did such voters become the target of vote buying because they had professed greater ideological proximity to the party? Or, did electoral handouts come first and then predict likelihood of being close to the party? The next question I discuss is variation across parties, and whether support for any particular political party is most closely identified with vote buying. Next, I examine the core- versus swing-voter models, highlighting evidence from a survey of politicians and brokers as well as qualitative data that seem to point to a tendency towards corevoter strategies among election practitioners. The chapter then discusses the apparent paradox that although in relative terms party loyalists are more likely to be targeted, and politicians and brokers confirm that such voters are their primary targets, in absolute terms most vote buying occurs among non-partisans. This finding leads to further puzzles with regard to whether failed targeting took place or whether there are other factors that can explain this pattern. The chapter, therefore, ends by setting up the key questions for the following chapters to tackle.

\subsection{Political Party Partisanship in Indonesia}

At the outset, it is essential to show the aggregate level of self-reported party identification in Indonesia based on my post-election survey of voters in April 2014. While there is much divergence of opinion on the nature and measurement of party closeness (Blais et al., 2001; Greene, 2002), this study measures the degree of partisanship regarding a political party by using the three items introduced in Chap. 3. Through the first measure, respondents were asked whether they feel close to any political party. In my post-2014 legislative election survey, only $14.9 \%$ (herein we round up to $15 \%$ ) nationally reported having such closeness-a low figure by international standards. As discussed in Chap. 2, there were around 187 million registered domestic voters in the 2014 legislative election. Hence, the $15 \%$ would mean an estimated 28 million voters nationwide felt close to a party.

For the purpose of this study, I categorised as 'non-partisan' those respondents who either gave a straight negative response or couldn't answer this question. Consequently, the number of non-partisans is - at $85 \%$ - extremely 


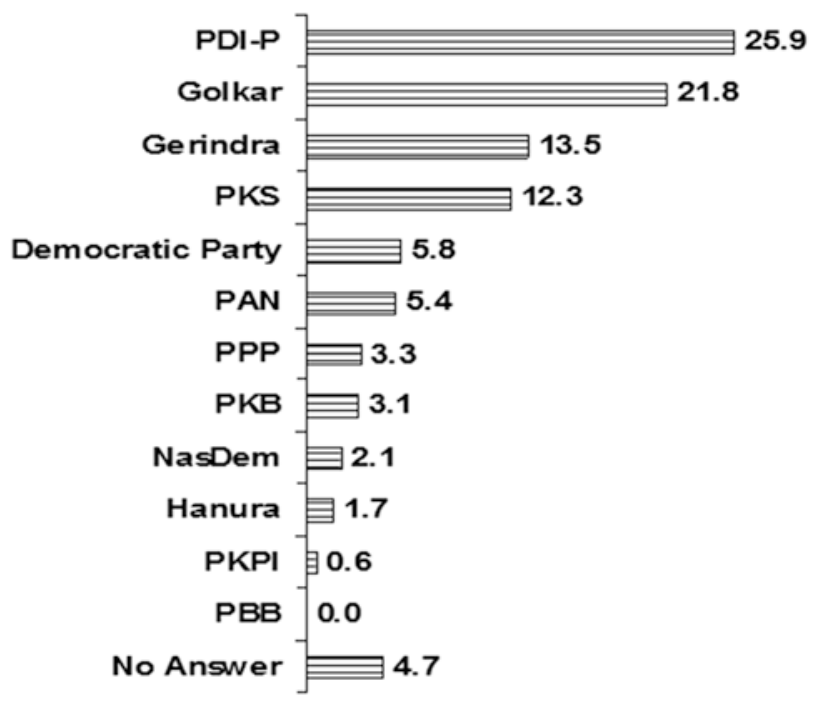

Fig. 4.1 Distribution of partisanship across political parties (\%). Source: My post-election survey, 22-26 April 2014

high, constituting the vast majority of the electorate, or about 159 million voters. As will be further demonstrated in the following section, this pattern was confirmed in a series of nationwide surveys during the run-up to 2014 elections.

Those who answered the opening question with 'yes' were requested to name the specific party they feel close to. Figure 4 .1 shows that mass partisanship in Indonesia varies widely across party distribution. Of those expressing partisanship, a quarter felt some degree of attachment to PDIP. Following PDI-P was Golkar with $21.8 \%$ and then Gerindra with 13.5\%. Thus, among those identifying partisanship, more than $60 \%$ of respondents felt close to one of the three largest parties. At the other extreme of the spectrum, we find parties with almost no partisans: $\mathrm{PBB}(0 \%)$ and PKPI $(0.6 \%)$. To some extent, the distribution of party loyalty reflects the distribution of votes in the 2014 parliamentary elections. The big three of partisan identifiers, PDI-P, Golkar, and Gerindra, were placed in the top three spots and in the same order in the election results. ${ }^{1}$ However, it is

${ }^{1}$ In 2009, the order of these parties weren't the same. In the February 2009 survey of LSI, among those reported being close to a party (19.7\%), 18.2\% felt close to the Democratic Party, followed by PDI-P (18.1\%), and Golkar (17.3\%). This further bolsters my argument as I will subtantiate later that even so-called 'partisans' may not be particularly loyal to their party. 
important to note that the vote totals for all parties were several times larger than the number of voters who expressed allegiance to those parties.

In the third and final measure, those who reported being close to a party were asked to rate the strength of this affiliation on a three-point scale: "How close do you feel toward the party?" Those who said 'very close' to the party were classified as strong partisans. Those who replied 'quite or fairly close' to the relevant party were categorised as moderate partisans, while those who reported 'a little close' to a party were classified as weak partisans. Among the $15 \%$ of the respondents who felt close to any party, moderate partisans were the largest subgroup (58\%), with weak partisans $(23.1 \%)$ and strong partisans (17.4\%) constituting much smaller segments. Note that those who reported having varying levels of closeness to a party are distributed across political parties.

The low scores of mass partisanship as discussed above leave a number of unanswered questions: if there are so few voters with clear and declared loyalty towards a particular party, why were candidates very keen to target such voters? In the same vein, considering the large proportion of nonpartisans with a greater potential to change their voting decisions if given benefits (Lindbeck and Weibull, 1987; Dixit and Londregan, 1996; Stokes, 2005), as thoroughly discussed in Chap. 1, why did political machines profess that these voters were secondary to their vote-buying strategies? And finally, given that in total numbers more non-partisans than partisans experienced vote-buying attempts, does that mean that candidates and brokers misdirected their vote-buying operations? But first, I will discuss whether or not voters' partisan closeness is entirely a result of their receiving electoral rewards.

\subsection{Is Party Identification Endogenous TO BENEFITS?}

The finding that party affiliation is a significant predictor of vote buying raises an important question about the potential of reverse causality. It may be argued, as Diaz-Cayeros and his collaborators (2012: 159) have done, that the linkage between partisanship and vote buying is a case of 'conditional partisan loyalty,' that is, it is strongly influenced by distribution itself. They argue that the driving factor behind politicians' tendency to funnel benefits to their own supporters is the endogeneity of partisan loyalties to material inducements (Diaz-Cayeros et al., 2012). Stokes and her colleagues (2013: 54) have indicated the same potential endogenous- 
loyalty problem, aptly summarising the problem as follows: rather than voters' political preferences attracting handouts, these electoral incentives may cause people to identify with and support the party that gives them.

We must discuss two important caveats when dealing with the probability of an endogeneity problem (Stokes et al., 2013: 54-55). Since this study relies on survey data, the problem of reverse causality might be the result of a measurement error. To minimise this potential bias, I developed survey instruments for measuring political party partisanship based on those proposed by the Comparative Study of Electoral Systems (CSES). These measurements are plausibly proven to attract answers that aren't caused by a respondent's receiving particularistic rewards. Additionally, I put the question about respondents' feelings about parties at the beginning of the relevant questionnaire section to avoid the possibility of being contaminated by later questions on whether they have received a gift or social benefits from a party or candidate. By doing so, this question order is expected to be statistically independent of respondents' potential responses that could take the rewards they receive into account. Nonetheless, this methodological survey approach doesn't yet fully address the probability that respondents could conceptualise party loyalty as conditional on the rewards they received, rather than fixed (Diaz-Cayeros et al., 2012: 23).

To test for endogeneity bias, this study presents very simple statistics. Figure 4.2 suggests that party loyalty in Indonesia isn't conditional on receiving offers of vote buying. If party loyalty was endogenous to distribution of rewards, we might expect that partisan party alignment would increase parallel to the gradual intensification of vote buying as an election approaches. The tracking polls I conducted in the lead up to the $2014 \mathrm{elec}-$ tions allow us to examine whether this occurred. The square dotted line traces the percentage of respondents who feel close to political parties, and the long dashed line pinpoints the percentage of respondents who experienced offers of electoral rewards. In order to detect potential reciprocal effects of vote-buying transactions on a recipient's 'closeness' to the party, we need to track the two lines over time. The square dotted line shows that the percentage of people who reported being targeted with benefits started at a low point in January 2014 but increased over the course of the campaign, from $4.3 \%$ in January to $8.1 \%$ in late February to early March, $10.7 \%$ in late March, and 25\% in the few days leading up to the election in April.

If the endogenous loyalty thesis were correct, party identification levels should have risen in concert with the dramatic increase of vote-buying incidents in the weeks leading to the poll. However, the square dotted line 


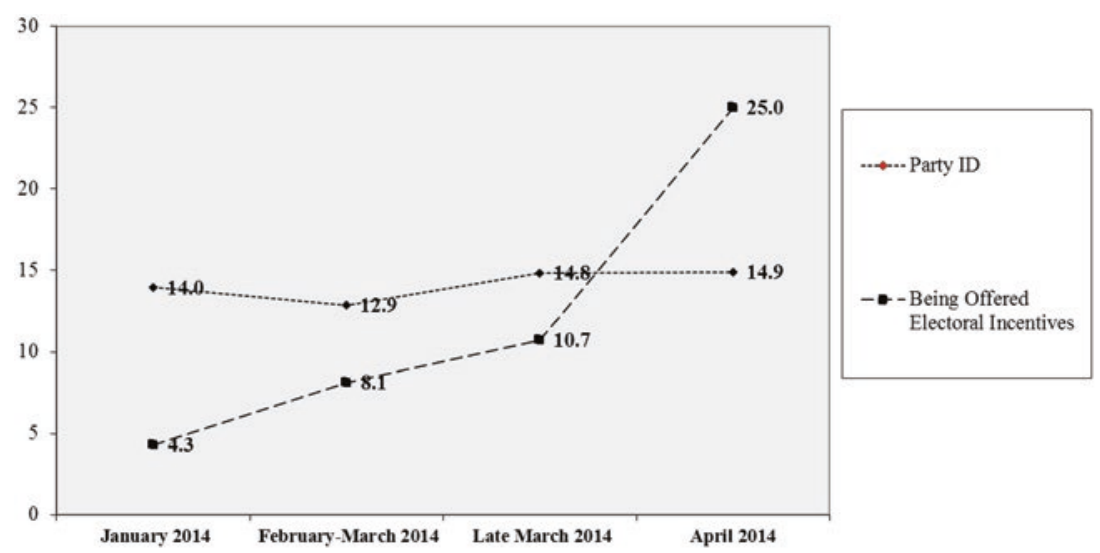

Fig. 4.2 Party identification and vote buying approaching the 2014 election (\%). Source: The January, February-March, and late March 2014 data were taken from my pre-election surveys, while the April 2014 numbers were drawn from my postelection survey (see Appendix A)

clearly indicates that partisan loyalties around the 2014 elections were relatively stable, ranging from $12.9 \%$ to $14.9 \%$. Put simply, party identification was virtually unaffected by short-term electoral incentives, providing evidence that the effect of voters' partisanship on their individual probability of being targeted by vote buying isn't endogenous, and that a voter's party loyalties in Indonesia aren't a function of his or her clientelist interactions with the party or its candidates. This finding is in line with the claims of early proponents of the concept of party identification, who defined party identification as a sense of personal, psychological attachment (Campbell et al., 1960) and viewed party identification as more of an identity than an opinion (Larcinese et al., 2012: 3). Partisanship, therefore, is independent of short-term factors such as vote buying.

\subsection{Variations in Party Identification by Party ANd Vote Buying}

Having ruled out the possibility of reverse causation, it is now important to examine whether partisanship towards any particular political parties is most closely identified with vote buying. Using data from my post-election survey in April 2014, it allows for a broader comparison across legislative, 
local, and presidential elections. I first recoded party identification into new variables consisting of partisan identities in each party. In every partyspecific partisanship, I transformed an existing variable into four categories reflecting varying degrees of partisanship. For instance, the partisanship to NasDem variable ('Nasdem partisan') was recoded into four categories: 0 refers to respondents who didn't identify with NasDem, including those who were ideologically indifferent or opposed to the party; 1 represents weak partisans; 2 points to moderate partisans; and 3 indicates strong partisans of NasDem. The same approach was used for other partisan variables in each political party. Afterwards, to measure the strength of a linear correlation between the two variables, each partisan identity was correlated with vote buying.

Table 4.1 shows important variations among core constituents of all parties. If we refer to the vote buying in legislative elections, partisans of the three big parties, PDI-P, Gerindra, and Democrats (as well as PKS), are more likely than others to be targeted for vote buying. Similarly, Golkar partisan affiliation has a markedly strong relationship with the overall vote-buying

Table 4.1 Correlations (Pearson's $r$ ) between party identification and vote buying

\begin{tabular}{|c|c|c|c|}
\hline & $\begin{array}{l}\text { Vote buying in } \\
\text { legislative elections }\end{array}$ & $\begin{array}{l}\text { Vote buying in presidential and } \\
\text { local executive elections }\end{array}$ & $\begin{array}{l}\text { Vote-buying } \\
\text { index }\end{array}$ \\
\hline $\begin{array}{l}\text { NasDem } \\
\text { partisan }\end{array}$ & -0.012 & -0.007 & -0.008 \\
\hline PKB partisan & 0.046 & 0.023 & 0.055 \\
\hline PKS partisan & $0.073^{*}$ & -0.037 & 0.036 \\
\hline PDI-P partisan & $0.096^{* *}$ & 0.011 & $0.080^{*}$ \\
\hline Golkar partisan & 0.058 & 0.037 & $0.062^{*}$ \\
\hline $\begin{array}{l}\text { Gerindra } \\
\text { partisan }\end{array}$ & $0.062^{*}$ & 0.023 & 0.047 \\
\hline $\begin{array}{l}\text { Democrats } \\
\text { partisan }\end{array}$ & $0.077^{*}$ & 0.055 & $0.083^{* *}$ \\
\hline PAN partisan & 0.059 & -0.011 & 0.036 \\
\hline PPP partisan & 0.034 & 0.020 & 0.041 \\
\hline $\begin{array}{l}\text { Hanura } \\
\text { partisan }\end{array}$ & 0.025 & $0.106^{* * *}$ & $0.073^{*}$ \\
\hline PBB partisan & (a) & (a) & (a) \\
\hline PKPI partisan & (a) & -0.012 & (a) \\
\hline
\end{tabular}

(a) Cannot be computed because at least one of the variables is constant (no cases)

${ }^{* * *} p<0.001,{ }^{* *} p<0.01,{ }^{*} p<0.05$ 
index. As discussed in Chap. 2, the vote-buying index is a composite statistic of vote buying in legislative elections and vote buying in presidential and local executive elections. In general, these statistical results correspond with findings from a related but differently worded question already analysed in Chap. 2: when asked which party or candidates offered goods or money, the most frequent answer was Golkar (32.2\%). Following Golkar are PDI-P (26.5\%), Gerindra (25\%), and the Democratic Party (18.4\%).

Alternatively, in order to examine partisanship with which party increases the likelihood of being offered benefits, I correlate the variables of party identification with clientelist exchanges in each political constituency. I conducted such correlation because there are predictable variations in the level of party identification across political constituencies and people who voted for certain political party weren't necessarily close to that party. The results, however, are generally similar to those produced by the first technique.

Table 4.2 reveals a clear positive correlation between party identification and clientelism in some political constituencies. Party-based identification among those who voted for PDI-P, Golkar, and Democratic Party in the 2014 legislative election correlates with greater

Table 4.2 Correlations (Pearson's $r$ ) between party identification and vote buying in each group of political constituencies

\begin{tabular}{llll}
\hline & $\begin{array}{l}\text { Vote buying in } \\
\text { legislative elections }\end{array}$ & $\begin{array}{l}\text { Vote buying in presidential and } \\
\text { local executive elections }\end{array}$ & $\begin{array}{l}\text { Vote-buying } \\
\text { index }\end{array}$ \\
\hline $\begin{array}{l}\text { Party identification in each group of } \\
\text { NasDem }\end{array}$ & $0.382^{*}$ & 0.109 & \\
PKB & 0.162 & 0.118 & 0.345 \\
PKS & $0.339^{*}$ & -0.043 & 0.180 \\
PDI-P & $0.253^{* *}$ & 0.089 & 0.257 \\
Golkar & $0.157^{*}$ & 0.096 & $0.222^{* *}$ \\
Gerindra & 0.146 & 0.118 & $0.154^{*}$ \\
Democratic & 0.220 & 0.173 & 0.172 \\
party & 0.117 & -0.033 & $0.248^{*}$ \\
PAN & $0.394^{* *}$ & 0.193 & 0.072 \\
PPP & $0.433^{* *}$ & $0.706^{* * *}$ & $0.420^{* *}$ \\
Hanura & -0.350 & -0.252 & $0.620^{* *}$ \\
PBB & $(\mathrm{a})$ & $(\mathrm{a})$ & -0.351 \\
PKPI & & (a) & \\
\hline
\end{tabular}

(a) Cannot be computed because at least one of the variables is constant (no cases)

${ }^{* * *} p<0.001,{ }^{* *} p<0.01,{ }^{*} p<0.05$ 
likelihood of engagement in vote buying, defined in this study based on a combination of responses to a battery of questions that inquired about respondents' exposure to such practices in the legislative elections as well as national and local executive elections (see Chap. 2). As can be seen in the third column of Table 4.2, the magnitudes of the relationship are strong since their substantive effects reach the 0.05 significance, or even more. Similar (but not entirely congruent) with the first model, when we restrict our analysis only to vote buying in legislative elections, partisan attachments among those who voted for PDI-P, Golkar, PKS, Hanura, NasDem, and PPP (thus more than half of all parties in the 2014-2019 parliament) are found to be significantly correlated with vote buying.

Overall, despite persons expressing party loyalty attracting benefits, we must be especially attentive to variations. Such relatively consistent findings between the two statistical techniques reinforce the notion that partisanship towards some parties doesn't automatically make such partisans a vote-buying target. Only where a positive, direct, and significant correlation with such handouts exists can we tie particular party-based partisanship to a higher likelihood of being targeted with clientelist techniques.

\subsection{Testing the Models of Distributive Politics}

\subsubsection{Evidence from Surveys of Local Politicians and Brokers}

In the preceding sections, I discussed survey data on the interplay between party identification and clientelism and addressed a number of methodological problems in analysing this interplay. This has put me in a position to now further review the debate about core and swing voters against the background of findings on the influence of voters' partisan predispositions.

So far, our examination about the conflicting strategies of core- or swing-voter targeting has only dealt with the demand side of vote buying, namely the voters. However, the supply side is equally important: how do candidates and brokers view the core- versus swing-voters dilemma? In order to take additional steps to explore whether candidates and brokers target core or swing voters in Indonesia, this section primarily draws from the survey of low-level politicians and brokers in four provinces (West Sumatra, Central Java, East Java, and North Sulawesi) I conducted in September and October 2014 and which was described in Chap. 1 and is 
explained in greater detail in Appendix B. This survey asked respondents numerous direct questions about their clientelistic practices. The total sample was 1199 respondents consisting of 299 provincial and district legislators and 900 brokers (known locally as 'success teams') who worked for them in the 2014 elections.

Stokes and her colleagues (2013: 31) argue that, faced with limited budgets, political parties and their candidates don't waste resources on targeting core voters with material inducements, assuming that they are likely to vote for them anyway. At the same time, however, rewarding voters who are ideologically distant from or opposed to the party or candidate is also considered wasteful (Stokes, 2005). Accordingly, candidates are assumed to reach out to swing voters in the middle of these two extremes, that is, uncommitted voters who will reciprocate with votes for any kind of gift. Reflecting these dynamics, political machines usually divide locales into three categories: party base, party opponent base, and locations of swing voters. It is important to note that the distinction between 'party base' and 'individual candidate base' is often blurred in the Indonesian context; I return to this point in Chap. 5. It is in this context that respondents in my survey addressed the question of whether they distributed largesse in party base, swing voter, or opponent base areas.

The possible overlap of party with personal networks notwithstanding, the results of the survey show that politicians and electoral brokers claimed to have distributed more benefits in their party base areas than in other territories (Fig. 4.3). This finding is, of course, inconsistent with the expectation inherent in the swing-voter hypothesis, and instead seems to confirm the notion of core-voter targeting proposed by Nichter (2008) and others (Cox and McCubbins, 1986; Diaz-Cayeros et al., 2012; Stokes et al., 2013). I didn't find considerable heterogeneity by province. Compared to their operatives or brokers, candidates exhibited even greater inclinations to funnel resources to locations where their parties performed well in the past. It is worth noting, however, that in the context of an open-list system-as I will further discuss in Chap. 5-contenders win seats not only by defeating candidates from other parties. More importantly, they have to beat co-partisans from their own party - and this makes the party base a particularly contested field. Consequently, party nominees 'individualise' the party base by distributing more resources to party supporters in an effort to maximise their individual votes from them. The implication is clear: they need to outdo their internal rivals in terms of patronage distribution. 


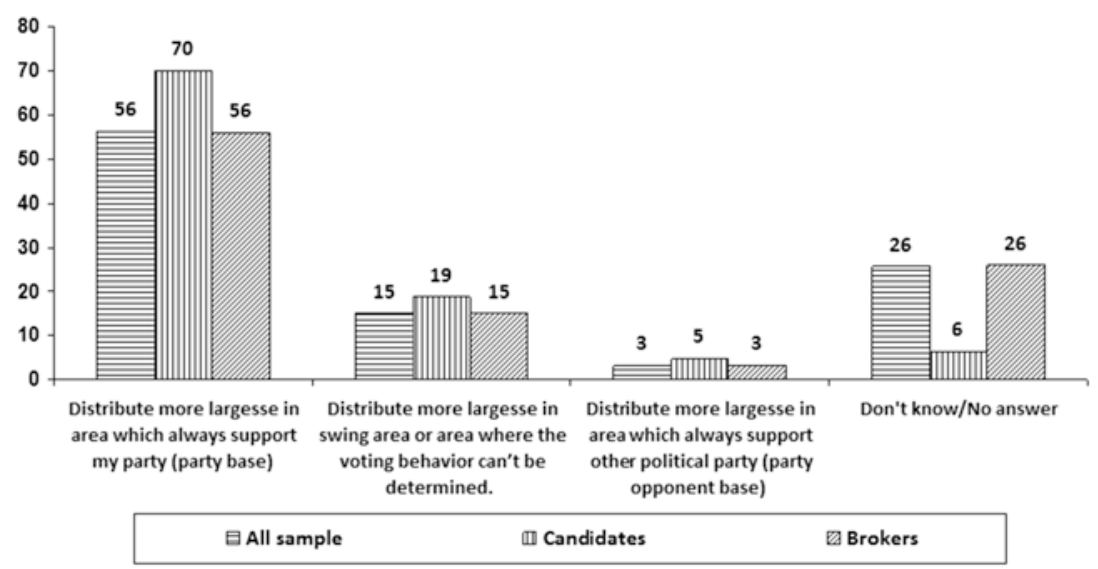

Fig. 4.3 Party base is the preferred target (\%) (All sample here represents a combination of local MPs and brokers. However, as indicated earlier, the proportion of brokers surveyed is much larger than the proportion of local politicians interviewed. See Appendix B.). The survey question used is: "During the last 2014 legislative election, how did you distribute largesse in order to get votes?" Source: My survey of low-level politicians and brokers, 30 September-25 October 2014

The same trend emerged from a measure that explored the priorities of resource allocation to different broker teams. The wording of the question was as follows: "There are two different success teams working in two different areas. One area is known as party base area, while the other is known as the swing competitive area for political parties. Between these two success teams, which one will get more money and logistical support from the party or candidate?" Figure 4.4 reveals that the majority of local MPs and brokers preferred to allocate more resources to campaign teams working in party strongholds than in swing areas. Again, the figure is strongly suggestive that Indonesian candidates prioritise mobilising their own party supporters: what Nichter (2010) famously called 'turnout buying,' and Schaffer and Schedler (2007: 25) briefly refer to as 'participation buying.'

In order to further consolidate the finding, I inserted an additional question on this matter in my broker survey: "If you distributed envelopes/staple goods package, which type of voters did you prioritise?" Three choices were provided: (1) Voters who regularly vote for the party I support; (2) Voters who regularly vote for another party; and (3) Voters whose voting behaviour cannot be determined. Over $75 \%$ of brokers 


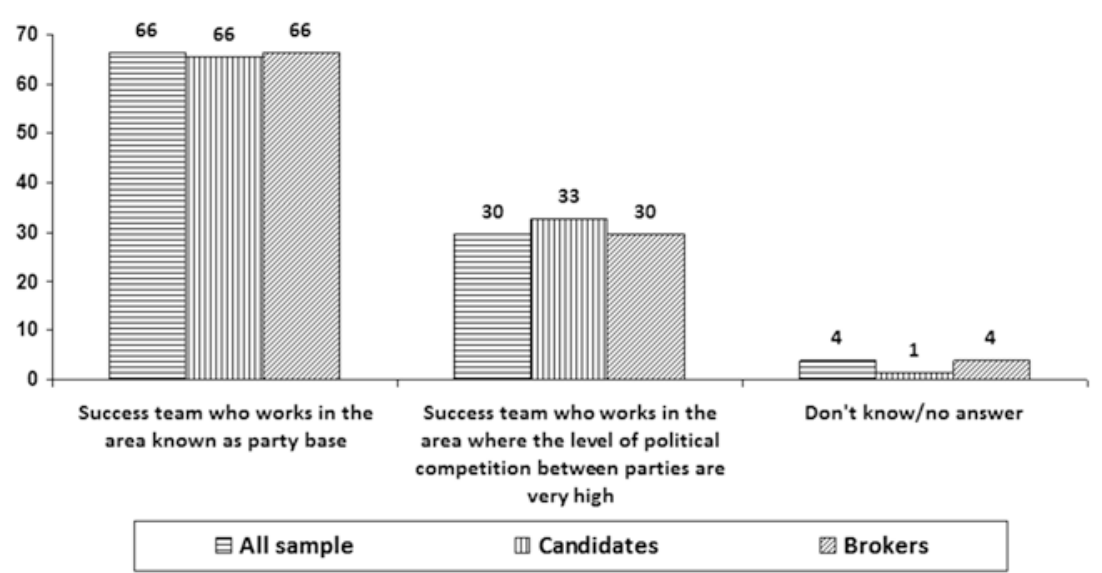

Fig. 4.4 Party base receives more resources (\%). Source: My survey of low-level politicians and brokers, 30 September-25 October 2014

admitted to targeting voters they thought of as being regular party supporters. Only one-fifth favoured swing voters, while only $2 \%$ preferred the supporters of rivals. Asked in an open-ended question to specify the main reason for prioritising such partisan, loyalist voters, the most typical response was that these voters were relatively certain targets. However, I found a significant variation to this trend in West Sumatra (as previously noted, an area of relatively low vote buying), where non-partisan voters were disproportionately targeted for vote buying. This stood in contrast to Central Java, East Java, and North Sulawesi, where brokers favoured those perceived as party loyalists over ideologically indifferent voters.

In short, the evidence emerging from the various surveys suggests that in Indonesia, brokers and candidates tend to direct patronage distribution flows during elections towards voters with strong party-based loyalties. As I will discuss in the following section, the logic behind this inclination to prioritise loyalists over swing voters is largely to reduce risk. Core supporters are seen as less risky, more responsive, and predictable targets, which is, at first glance, consistent with the core-voter argument.

\subsubsection{Reasons Behind the Tendency to Favour Core Voters}

\subsubsection{Double-Layered Risk Aversion}

Having stated the favoured tendency among political actors, I now turn to delve more deeply into explanations for why candidates and brokers 
preferred to channel benefits to party loyalists rather than to uncommitted voters. In order to explain the logic behind their proclaimed core-voter strategies, I draw from the survey of local politicians and brokers and indepth interviews with national politicians. After posing the hypothetical questions analysed above, I asked brokers and candidates for a spontaneous response to an open-ended question explaining their choice. As in Fig. 4.5, the respondents who reported expressing a strong desire to target loyalists (recall that this was the majority of politicians and brokers) did so due largely to reduce risk as core supporters are seen as less risky, more responsive, and predictable.

This finding was echoed by many candidates I interviewed during my 13 months of fieldwork in Indonesia. Many stated that they were mostly concerned about the threat of opportunistic defection by voters when engaging in vote buying. In order to minimise uncertainty over whether or not the recipient would repay the supplied benefits with votes, riskaverse candidates tend to target their assumed core supporters whose support can-according to the expectations of campaign organisers-be maximised by increasing turnout. In short, the strong preference to favour
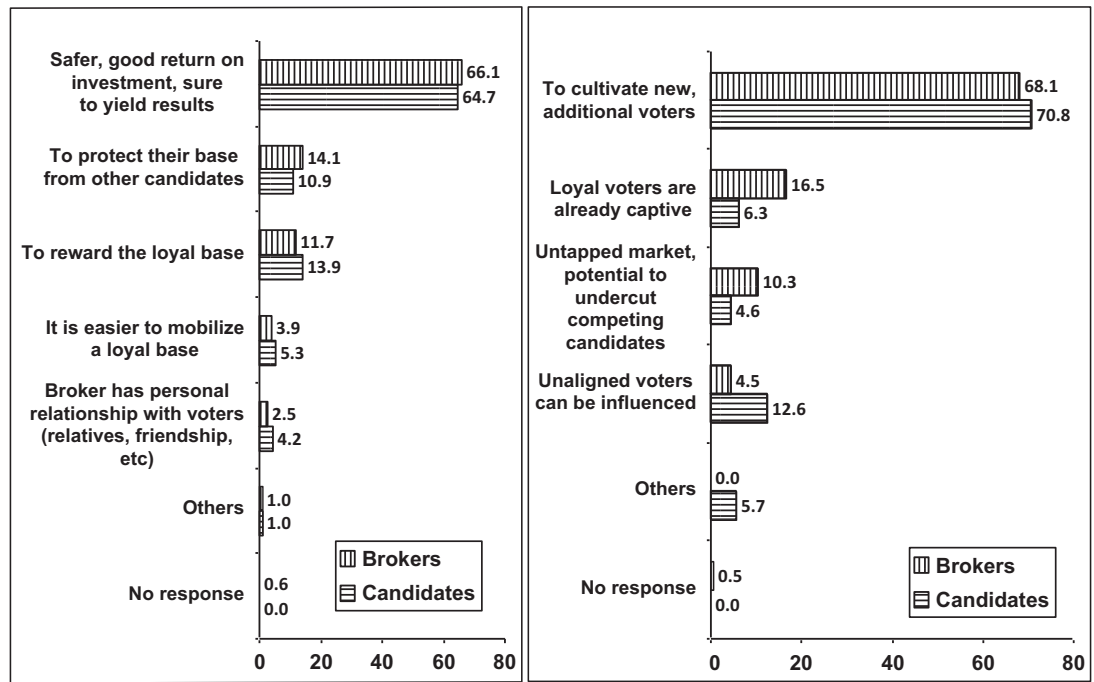

Fig. 4.5 Why do success team members target loyalists (left panel) or uncommitted voters (right panel)? (\%). Source: My survey of low-level politicians and brokers, 30 September-25 October 2014 
core supporters reflects the search for certainty among both candidates and intermediaries. Thus, this study confirms propositions by early corevoter theorists (Cox and McCubbins, 1986: 379) who argued that political actors are inherently risk-averse and are reluctant to shower benefits on swing voters because many such voters might defect.

This analysis is supported by my targeted interviews with national-level politicians. One prominent national politician from the traditionalist Muslim party PKB (National Awakening Party) which was founded by Nahdlatul Ulama (NU), Indonesia's largest traditionalist Muslim organisation, admitted that most of his campaign benefits were distributed to his party's bases. He explains:

I asked my teams to deploy more resources to traditionalist santri (devout Muslim) bases because they are the most reliable voters with the highest electoral potential. Those affiliated to NU, the traditionalist santri are my party's real constituency. ... For me, targeting NU followers that are closely connected historically as well as ideologically to PKB was more appealing and much more certain. (Interview, 18 April 2014)

A successful candidate from the Islamist party PPP (United Development Party) employed a portfolio of strategies that maximised his electoral support by investing in the loyalty of his own party and personal supporters. Asked why he predominantly distributed campaign benefits to loyal supporters, the candidate, who was running in South Kalimantan, where Banjarese were the largest ethnic group, cited a local philosophy: "Jangankan haruan' ganal, haruan halus haja bisa meluncat" (never mind a big fish, even a small fish can escape you). In other words, his view was that loyal supporters are like small fish, whose support is hard enough to secure, while targeting 'big fish' (in this case, swing voters) is much more difficult, needing a lot of effort and resources (Interview, 21 July 2014). Similarly, a candidate from the modernist Islam party PAN explored how potential electoral return rises with an increase in risk. Though uncommitted voters make up a much higher proportion of the electorate, he argued, they are typically associated with high levels of uncertainty. "Pursuing swing voters isn't only a difficult task, but it would also mean overlooking loyal supporters as a captive (pangsa pasar) vote," he explained (Interview, 22 April 2014).

\footnotetext{
${ }^{2}$ Harnan is a species of snakehead fish, an indigenous freshwater fish of Banjar and a common food item among the local populace.
} 
In many electoral territories, there are local equivalents to the Banjarese phrase cited above, and candidates often mentioned them in interviews with me. These phrases generally suggest that individuals operating under conditions of uncertainty should avoid risk, ${ }^{3}$ with many running along the lines of 'take care of your own' and 'secure your possessions!' (Holder, 1975, cited in Cox and McCubbins, 1986: 383). For instance, a candidate from Hanura focused on turning out his (potential) masses in his electoral district in Central Java so his campaign largesse wasn't wasted (Interview, 14 May 2014). A prominent national leader of $\mathrm{PKB}$, on the other hand, admitted that targeting unknown people was like making a bargain with an uncertain payoff-and costly as well (Interview, 20 April 2014). In emphasising the unreliability of such voters, many candidates characterised undecided voters as 'tidak jelas' (uncertain) or 'tidak bisa dipegang' (unreliable, lit. 'cannot be held'). In contrast, they perceived loyal supporters to have what Diaz-Cayeros and his colleagues (2016:71) called "a high level of adherence" that makes them more responsive to quid pro quo exchanges. In summary, the important driver behind candidates' preference for capturing loyalists was an operational rationalisation of their personal tendency towards risk aversion.

\subsubsection{The Moral Economy of Vote Buying}

In addition to being rationalised as the most effective and low-risk strategy, some political operators justify and explain the targeting of party loyalists as an act of gift giving-a moral duty, even. As shown in the left panel of Fig. 4.5, when asked why they targeted loyal voters, many of the surveyed candidates and brokers defended it as a reward, a sign of attention or reciprocal action for their supporters. In such cases, as argued by Walker (2014), vote buying isn't defined in terms of economic market transactions; rather, it is a function of complex social relations entangled in a traditional moral economy of exchanging votes for gifts (Aspinall et al., 2017: 4).

In the interpretation of cash handouts or small favours to voters as a ritual gift exchange rather than as an act of blatant vote buying, the recipients don't object to the payment because it isn't seen as a bribe for their

\footnotetext{
${ }^{3}$ To mention a few: There is a Javanese proverb "ojo mburu uceng neng kelangan deleg" (don't chase small fish while losing more valuable goods), or the Sundanese phrase: "moro julang ngaleupaskeun peusing" (being tempted by other goods may cause us to overlook our belongings).
} 
votes (Walker, 2014). Instead, they might consider it as part of a moral economy closely associated with elections, or perceive it as signalling "the positive personal qualities of the giver, such as generosity, politeness, responsiveness, and respect... [that] lead citizens to believe that the candidate is good or worthy" (Schaffer and Schedler, 2007: 26). Accordingly, embedding vote buying within social norms of reciprocity helps generate a feeling of obligation on the part of beneficiaries to reciprocate with support (Schaffer, 2007: 193; Aspinall et al., 2017).

Around Asia, there are many terms to describe this phenomenon. The Indonesian trait of butang budi (norm of reciprocity) is somewhat akin to utang na loob in the Philippines (Alejo et al., 1996: 84) or guanxi (关系) in China (Wang, 2013: 4-5). In Indonesia, it is said that once a person has granted us a favour, we should do everything to pay that favour back to him/her, sometimes even at the expense of ourselves. Vote buying fits into this culture of mutual favours, in which candidates are happy to provide small gifts and voters are happy to give their vote. Many candidates typically describe gifts as mang saku ('pocket money'). The standard justification is that the 'gift' is given to compensate loyal supporters for the time they lose by going to polling stations (Aspinall et al., 2017: 11). Edi Inrizal, an anthropologist from University of Andalas, Padang, West Sumatra, argued that Indonesians tend to favour indirect references and transactions over blunt treatments of realities. Thus, monetary exchanges need to be packaged in language of morality and generosity. In this context, he mentioned a saying, 'kanai pacak' (splash out a little money), which is often applied to gift giving in elections. For ordinary people, political power is often equated with big resources and money, so those running for it should distribute small amounts of money to their voters as a cultural token of gratitude (Edi Inrizal, Interview 21 September 2014).

Such practices and the beliefs that legitimate them aren't only limited to voting day, however. When visiting influential religious or other local leaders during the campaign, Hanif Dhakiri from PKB, for instance, didn't come empty-handed, providing them with religiously symbolic goods such as peci (associated with Muslim men's hats), sarongs, or even money (Interview, 26 August 2014). Many other candidates did the same thing. They often call these gifts as 'buah tangan' (keepsake) or 'tanda mata' (souvenir). Despite the cost that these items incur, there is a widely held view among politicians that allocating resources to loyal supporters isn't as costly as giving to undecided voters. In an attempt to show that core 
voters are generally the cheapest target, a PAN candidate, running in one electoral district in East Java, explained that

Unlike swing or transactional voters, investing in loyal voters doesn't cost a lot. For Javanese, providing money gifts to loyalists is regarded as bisyarah or a sign of love.... It isn't peningset ... something that binds. At Javanese weddings, the groom gives expensive presents to bind the bride (peningset). Instead of binding voters with expensive gifts or big money, bisyarah is simple and a cultural tradition. (Interview, 22 April 2014)

Another successful candidate from the Democratic Party, who was running in an electoral district in West Java, confirmed the notion that

Bisyarah parallels with cultural values. It isn't only a Javanese, but an Indonesian tradition. If you are seeking people's votes, you have to have good understandings. People who are going to vote for me would be unable to work on voting day. I compensate them for that. It isn't expensive, just keepsakes to 'tie' them so they don't run to cashed-up rivals. If you give your loyal supporters just IDR 10,000 each, that would be enough. Even if a competitor swamped them with big money, let's say IDR 100,000, they would still deliver their votes to us. (Interview, 25 April 2014)

It is noteworthy that candidates and brokers often feel a high level of anxiety if they don't comply with the social norm of gift giving. It has virtually become conventional wisdom among practitioners in Indonesia that voters who initially support one particular candidate but don't receive gifts can end up voting for more cashed-up rivals. This is particularly so because although voters might be party loyalists, they still have to pick between several candidates from that party (see Chap. 1). As shown in the left panel of Fig. 4.5 above, $11 \%$ of surveyed candidates and $14 \%$ of brokers showered their supporters with benefits to protect their bases from other (internal) competitors. Hajriyanto Thohari from the nationalist Golkar party was told by his success team members that they needed to make cash payments in order to secure their votes a few days before the election. Hajriyanto mentioned a term being used to describe this practice: tembakan terakhir or 'final shot.' He said: "I rejected their suggestion. They replied that they wouldn't be responsible if I failed to get the seat. ... I didn't make it, despite the fact that I had been previously elected many times in this electoral district" (Interview, 21 April 2014). 
Similarly, a prominent PKB politician admitted: "I distributed patronage or money to tie them to me. ... just small sums of money. ... These minor gifts... ensure that the voters I had been cultivating don't switch to opponents" (Interview, 20 April 2014). As I will argue in more detail in Chap. 5, higher uncertainty as a result of the open ballot system and intense intraparty competition drives candidates to-in a term they frequently used'tie' (mengikat) their loyalists with cash, so they wouldn't turn their backs on them. These findings are somewhat similar to those of Dunning and Stokes (2008) in Mexico, where many initial supporters of the Party of the Institutionalised Revolution (PRI) finally voted for rivals because they didn't get any electoral incentives. In Indonesia, however, things are even more complicated because although voters might remain loyal to a party, they still can vote for a different candidate within that party. When parties must distribute benefits to sustain partisan loyalty, Dunning and Stokes called the relevant voters' attitude 'conditional loyalty.' Overall, despite the cultural norm of gift giving in Indonesia motivating candidates to cultivate their core supporters, the dominant discourse among candidates is that a significant proportion of their so-called loyalists would change their votes if they didn't receive assistance. Again, my findings from broker and candidate survey as well as qualitative interviews support the notion that partisan, loyalist voters are widely favoured as vote-buying targets among political actors.

\subsubsection{Evidence from Nationwide Surveys}

In this section, I return to analysing voter-level data in order to obtain more detailed information on who receives offers of material benefits, and when. By adding temporal dimensions these data (see Table 4.3 below) are again highly supportive of the party-loyalist strategy and explain in which period party loyalists receive the most offers of benefits. Non-party identifiers were consistently less likely to be offered gifts across four surveys in 2014 leading up to the election. Using the statistical analysis approach of relative risk or risk ratio ( $R R$ ), the probability of self-proclaimed partisan voters experiencing vote buying was two or three times higher than that of non-identifiers. For example, in January 2014, 9.1\% of the respondents with partisan closeness were being offered rewards, but only $3.5 \%$ of those with no partisanship were targeted-a proportional difference of $(9.1-3.5) / 3.5$ or around 1.55 (or $155 \%)$. The same also held true in late February and early March 2014, about one and a half months before the election, with a proportional difference of 1.96 or $196 \%$. 
As the election approached, the pace of vote buying accelerated as both party loyalists and uncommitted voters were increasingly targeted. In April 2014 , about $25 \%$ of respondents were exposed to such transactions. However, when restricting my analysis only to those with or without partisanship, $43.1 \%$ of the party identifiers were offered rewards. By now, $21.8 \%$ of the non-identifiers had been offered rewards too, a big jump from 3.5\% in January, 6.5\% in late February to early March, and 9.1\% in the end of March. Once again, consider that this segment of non-identifiers constitutes $85 \%$ of the total electorate. Indeed, it appears that the machines were still taking care of core constituencies, with proportional differences of $1.18(118 \%)$ and 0.98 (98\%) in late March 2014 and April 2014, respectively. Relative to previous results, however, the overall percentage of investment in core voters slightly decreased, while that in non-partisan voters markedly increased. The statistical risk ratio of partisans being targeted in January and February-March 2014 was two to three times more likely than that of non-identifiers, but this probability slightly decreased to only two times in the end of March and April 2014 (Table 4.3).

Table 4.3 Individual vote buying by some or no partisanship (\%)

\begin{tabular}{|c|c|c|c|c|c|}
\hline & & \multicolumn{4}{|c|}{$\begin{array}{l}\text { Reported having been the target of vote } \\
\text { buying }\end{array}$} \\
\hline & & Yes & No & Don't know & Total \\
\hline \multirow[t]{4}{*}{ January 2014} & Some partisanship & 9.1 & 90.1 & 0.8 & 100 \\
\hline & No partisanship & 3.5 & 94.3 & 2.1 & 100 \\
\hline & Relative risk & 2.6 & & & \\
\hline & Proportional difference & 1.55 & -0.04 & & \\
\hline \multirow[t]{4}{*}{ February-March 2014} & Some partisanship & 19.2 & 75.9 & 4.9 & 100 \\
\hline & No partisanship & 6.5 & 90.2 & 3.3 & 100 \\
\hline & Relative risk & 3.0 & & & \\
\hline & Proportional difference & 1.96 & -0.16 & & \\
\hline \multirow[t]{4}{*}{ Late March 2014} & Some partisanship & 19.9 & 76.8 & 3.3 & 100 \\
\hline & No partisanship & 9.1 & 86 & 4.8 & 100 \\
\hline & Relative risk & 2.2 & & & \\
\hline & Proportional difference & 1.18 & -0.11 & & \\
\hline \multirow[t]{4}{*}{ April 2014} & Some partisanship & 43.1 & 55.8 & 1.1 & 100 \\
\hline & No partisanship & 21.8 & 75.2 & 3.0 & 100 \\
\hline & Relative risk & 2.0 & & & \\
\hline & Proportional difference & 0.98 & -0.26 & & \\
\hline
\end{tabular}

Source: The January, February-March, and late March 2014 data were taken from my pre-election surveys, while the April 2014 numbers were drawn from my post-election survey (see Appendix A) 
From the data above, it is evident that candidates simultaneously target party loyalists and non-partisan voters, and the proportion of the latter increases as election day nears (while partisans are still clearly preferred in relative terms). However, such interpretations contradict the results from my sample survey of low-level politicians and brokers, as well as my in-depth interviews with high-level politicians. These political operators repeatedly expressed a strong preference for targeting loyalists. They believed that investment in uncommitted voters might be wasted. If they showed such strong preference to capture core supporters in their strategic thinking, why did they end up distributing so much cash and goods to so many non-partisan voters? This question is particularly relevant given that, it will be recalled, that in total numbers, non-party identifiers heavily outnumbered party identifiers, meaning that more voters without partisan attachments received offers than those with such attachments. This is the puzzle I develop in the last sections of this chapter-a puzzle that the following chapters then try to resolve.

\subsection{Mixed Results}

The puzzle described above is further illustrated in a last presentation of survey results comparing levels of vote buying in the 2014 and 2009 elections in relation to voters' partisanship. As shown in Figs. 4.6 and 4.7, the incidence of vote buying increased from 2009 to 2014, but the pattern in regards to partisanship remained the same: in relative terms, partisan

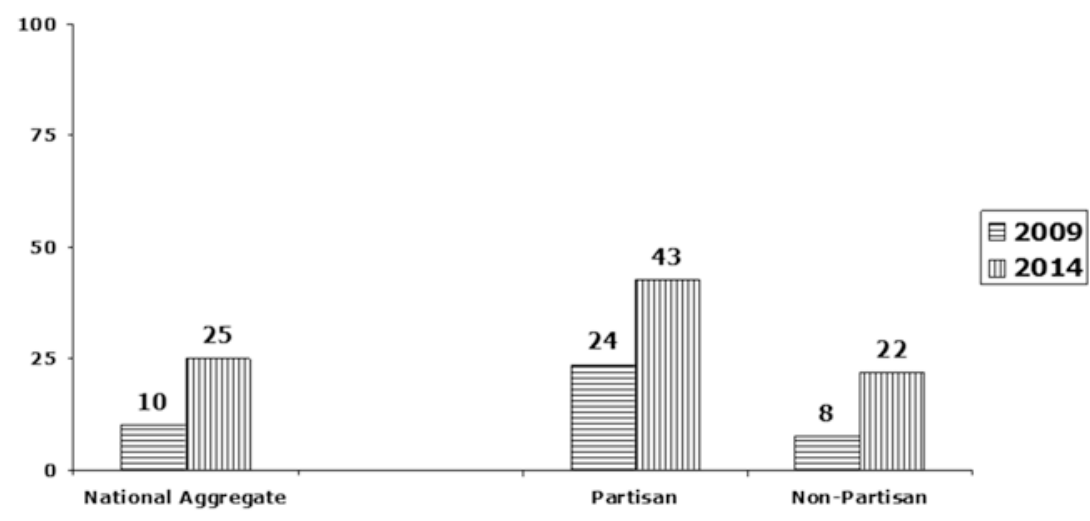

Fig. 4.6 Gift receipt by partisan effect: Direct vote buying (\%). Source: My postelection survey, 22-26 April 2014 


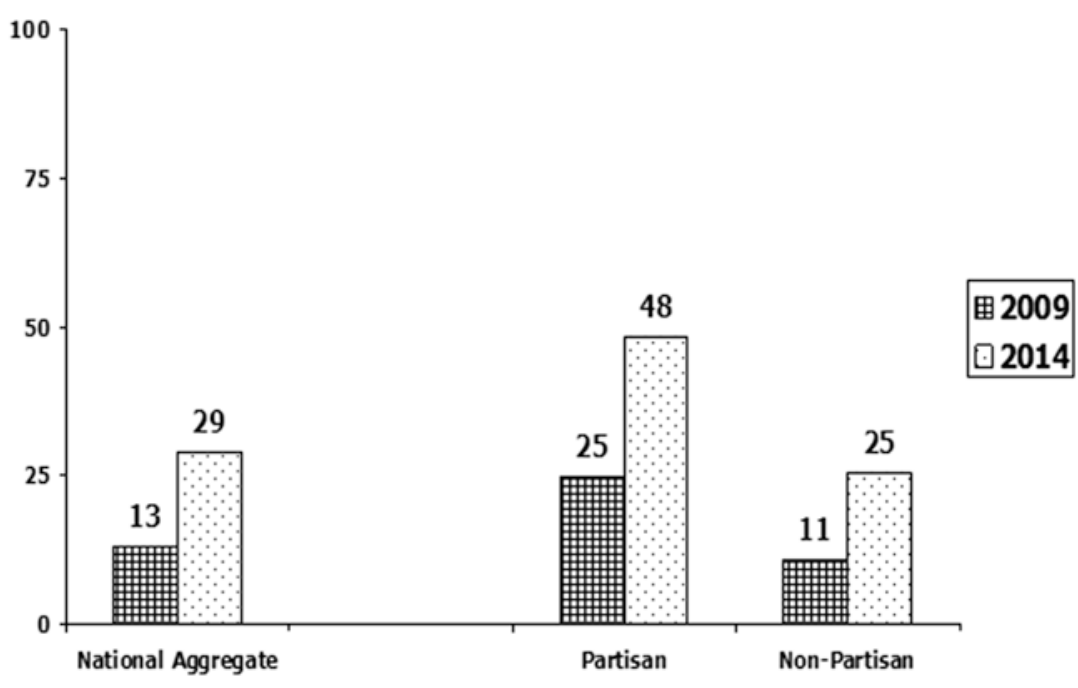

Fig. 4.7 Gift receipt by partisan effect: Neighbourhood vote buying (\%). Source: My post-election survey, 22-26 April 2014

voters were more likely to be targeted, but in total numbers, uncommitted voters who received benefits outnumbered the core voters who did so.

If we use a purely percentage-based analysis, the analysis of the survey data, and of the Indonesian case, presented so far provides strong support for the core-voter model, according to which partisan orientation increases the likelihood of a person receiving benefits during an election. This is true for both direct (Fig. 4.6) and neighbourhood measures (Fig. 4.7), which consistently show that if a voter identified with a party, then he or she was more likely to receive offers of vote buying than someone who wasn't a partisan.

If we rely on the absolute approach, by contrast, we come to a different conclusion-one that the swing-voter school of vote buying would prefer. As shown in Fig. 4.6, 'only' $22 \%$ of non-partisans received gifts during the 2014 campaign. However, these are $22 \%$ of the vast majority of voters ( $85 \%$ of the total electorate). By contrast, the $43 \%$ of loyal, partisan voters who received gifts sounds large, but they only make up a tiny percentage of the electorate. Put in a different way, $22 \%$ of $85 \%$ is much larger than $43 \%$ of $15 \%$. Recall that there were approximately 187 million voters in the 2014 election. This means there were almost 35 million non-partisan 
voters who received offers of vote buying but only 12 million partisan voters were exposed to such exchange. The numbers also bear out that vote buying increased faster among uncommitted voters than among party loyalists. It roughly tripled in the former category, while it only approximately doubled in the latter between 2009 and 2014 (based on the direct measure). Clearly, the voter survey data lead to differing - and, depending on the approach, even conflicting-interpretations on how to locate Indonesia in terms of the swing-versus loyalist-voter debate on vote-buying targets.

\subsection{Conclusion}

This chapter has discussed-from a number of methodological, empirical, and statistical perspectives - the effect of partisanship on vote buying. For the purpose of this study, the finding that party identification levels in Indonesia are low is crucial-only $15 \%$ of the electorate feel close to a political party. In order to avoid vulnerability to endogeneity assumptions, I further demonstrated that partisanship - as measured by my surveysisn't endogenous to electoral bribes. From this firmer methodological platform, I was able to show that there are variations in the effects of partisanship across the party spectrum, and in terms of the receipt of votebuying offer. Two different statistical analyses allowed us to assess that relative to other partisanships, those who are aligned with PDI-P, Golkar, and the Democratic Party (and other smaller parties depending on the measure) have a higher probability of being targeted with benefits than partisans of other parties. Roughly, the larger the party, the higher the chance a loyalist to that party has of being hit by vote buying.

But given that partisans are low in number and non-partisans constitute the vast bulk of the electorate, how do political operators themselves explain how they direct their limited resources during campaigns? My novel dataset from low-level politicians and brokers found that they indeed professed that they targeted loyalists. This pattern was confirmed by in-depth interviews with high-level politicians. The rationales behind this preferred strategy were associated with risk aversion and the moral economy of vote buying. Yet additional individual-level data showed that while in relative terms, partisans were more likely to be targeted, in absolute terms, more swing voters received rewards. In essence, then, neither the core-voter nor the swing-voter model is fully applicable in Indonesia. Political operators claim to target loyalists, and they indeed reach a significant number of them with their vote-buying efforts. But 
vote buying is so extensive and the number of partisans so small, that in reality much of the cash and gifts are absorbed by swing voters. Is this the result of failed targeting on the part of the operators? Or did candidates and brokers misunderstand who exactly was a loyalist and who was a swing voter, leading them to believe they targeted the former but ultimately hit the latter? Or were other mechanisms at work? The discussion above systematically set up this puzzle, which I address in the next chapter.

\section{BiBLIOGRAPHY}

Books, Journal Articles, and Unpublished Papers

Alejo, M.J., Rivera, M.E., and Valencia, N.M. (1996) [De]Scribing Elections: A Study of Elections in the Lifeworld of San Isidro. Quezon City: Institute for Popular Democracy (IPD).

Aspinall, E., Rohman, N., Hamdi, A.Z., Rubaidi, and Triantini, Z. (2017) Vote Buying in Indonesia: Candidate Strategies, Market Logic and Effectiveness. Journal of East Asian Studies 17: 1-27.

Blais, A., Gidengil, E., Nadeau R., and Nevitte, N. (2001) Measuring Party Identification: Britain, Canada, and the United States. Political Behavior, 23(1): 5-22.

Campbell, A., Converse, P.E., Miller, W., and Stokes, D. (1960) The American Voter. New York: John Wiley \& Sons.

Cox, G.W. and McCubbins, M.D. (1986) Electoral Politics as a Redistributive Game. The Journal of Politics 48(2): 370-389.

Diaz-Cayeros, A., Estévez, F., and Magaloni, B. (2012) Strategies of Vote Buying: Democracy, Clientelism and Poverty Relief in Mexico. Viewed at https://web. stanford.edu/ magaloni/dox/2012strategiesvotebuying.pdf. Accessed 17 October 2015.

- (2016) The Political Logic of Poverty Relief: Electoral Strategies and Social Policy in Mexico. Cambridge: Cambridge University Press.

Dixit, A. and Londregan, J. (1996) The Determinants of Success of Special Interests in Redistributive Politics. Journal of Politics 58(4): 1132-1155.

Dunning, T. and Stokes, S. (2008) Clientelism as Persuasion and as Mobilization. Paper presented at the annual meeting of the American Political Science Association, 28-31 August, Boston, MA.

Greene, S. (2002) The Social Psychological Measurement of Party ID. Political Behavior 24(3).

Larcinese, V., Snyder, J.M. JR. and Testa, C. (2012) Testing Models of Distributive Politics Using Exit Polls to Measure Voters' Preferences and Partisanship. British Journal of Political Science (November): 1-31. 
Lindbeck, A. and Weibull, J.W. (1987) Balanced-budget Redistribution as the Outcome of Political Competition. Public Choice 52: 273-297.

Nichter, S.C. (2008) Vote Buying or Turnout Buying? Machine Politics and the Secret Ballot. American Political Science Review 102(1):19-31.

- (2010) Politics and Poverty: Electoral Clientelism in Latin America. PhD thesis, University of California at Berkeley, USA.

Schaffer, F.C. (2007) Elections for Sale: The Causes and Consequences of Vote Buying. Colorado: Lynne Rienner Publisher, Inc.

Schaffer, F.C. and Schedler, A. (2007) What is Vote Buying? In: F.C. Schaffer (ed) Elections for Sale: The Causes and Consequences of Vote Buying. Boulder: Lynne Reinner.

Stokes, S.C. (2005) Perverse Accountability: A Formal Model of Machine Politics with Evidence from Argentina. American Political Science Review 99(3): 315-325.

Stokes, S.C., Dunning, T., Nazareno, M., and Brusco, V. (2013) Brokers, Voters and Clientelism: The Puzzle of Distributive Politics. New York: Cambridge University Press.

Walker, A. (2014) Vote Buying-Commodity or Gift? New Mandala, 13 April. www.newmandala.org/vote-buying-commodity-or-gift/. Accessed 15 June 2016.

Wang, T. (2013) Talking to Strangers: Chinese Youth and Social Media. PhD dissertation, the University of California, San Diego, USA.

Open Access This chapter is licensed under the terms of the Creative Commons Attribution 4.0 International License (http://creativecommons.org/licenses/ by $/ 4.0 /$ ), which permits use, sharing, adaptation, distribution and reproduction in any medium or format, as long as you give appropriate credit to the original author(s) and the source, provide a link to the Creative Commons licence and indicate if changes were made.

The images or other third party material in this chapter are included in the chapter's Creative Commons licence, unless indicated otherwise in a credit line to the material. If material is not included in the chapter's Creative Commons licence and your intended use is not permitted by statutory regulation or exceeds the permitted use, you will need to obtain permission directly from the copyright holder.

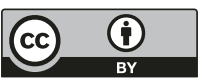

